\title{
Mapowanie diagnoz ICNP® na przykładzie procesu pielęgnowania dziecka $w$ przebiegu mononukleozy zakaźnej
}

The ICNP® terms cross-mapping on the example of nursing care of patient with rheumatoid arthritis

\section{ELŻBIETA NAZAR¹, DOROTA KOCHMAN², JOANNA PRZYBYLSKA²,3}

\author{
1 Studenckie Koło Naukowe Nauk o Zdrowiu, Instytut Nauk o Zdrowiu PWSZ \\ we Włocławku, opiekun Koła: dr Beata Haor \\ ${ }^{2}$ Instytut Nauk o Zdrowiu PWSZ we Włocławku \\ ${ }^{3}$ Miejski Zespół Opieki Zdrowotnej Sp z o.o. we Włocławku \\ DOI: http://dx.doi.org/10.21784/IwP.2018.017 \\ ISSN: 2451-1846
}

\section{Streszczenie:}

Wstęp. Mononukleoza zakaźna jest chorobą wywoływaną przez wirus Ebsteina-Barr (EBV) należącego do grupy wirusów Herpes. Wywołuje zakażenia w każdej grupie wiekowej, najczęściej u małych dzieci, nastolatków i młodych dorosłych. Objawy charakterystyczne to zapalenie gardła, gorączka i limfadenopatia. Udowodniono także związek pomiędzy zakażeniem EBV a nowotworami złośliwymi. Mononukleozę diagnozuje się na podstawie morfologii krwi obwodowej $\mathrm{z}$ rozmazem i aktywności aminotransferaz.

Cel. Celem pracy było zaprezentowanie planu opieki pielęgniarskiej nad dzieckiem $\mathrm{z}$ mononukleozą zakaźną $\mathrm{z}$ zastosowaniem klasycznej terminologii oraz pojęć z ICNP®. 
Materiały i metody. W pracy wykorzystano metodę analizy literatury poświęconej zagadnieniom opieki nad dziećmi z mononukleozą zakaźną oraz metodę studium przypadku. Terminy opisujące praktykę pielęgniarską zaczerpnięto ze słownika ICNP®.

Podsumowanie. Zaprezentowany $\mathrm{w}$ pracy plan opieki stanowi propozycję korzystania z klasyfikacji ICNP® dla potrzeb dokumentowania praktyki pielęgniarskiej.

Słowa kluczowe: proces pielęgnowania, ICNP®, mononukleoza zakaźna

\begin{abstract}
Introduction. Infectious mononucleosis is a disease caused by the EbsteinBarr virus (EBV) belonging to the Herpes virus group. It causes infections in all age groups, most often in young children, adolescents and young adults. Symptoms include pharyngitis, fever and enlarged lymph nodes. There is a proven link between EBV infection and malignant tumors. Mononucleosis diagnosis is based on the laboratory tests (full blood count) and transaminases.
\end{abstract}

The aim. The aim of the study was to present a nursing care plan for a child with infectious mononucleosis using classic terminology and concepts from ICNPß.

Materials and methods. The work uses the method of literature analysis devoted to the issues of child care with infectious mononucleosis and the case study. The terms describing nursing practice were taken from the ICNP $®$ dictionary.

Results and conclusions. The care plan presented is an example of the ICNP® classification use for the needs of nursing practice documentation.

Keywords: nursing process, ICNP®, infectious mononucleosis

\title{
Wstęp
}

Międzynarodowa Klasyfikacja Praktyki Pielęgniarskiej ICNP® to pierwszy międzynarodowy standard $\mathrm{w}$ pielęgniarstwie, który pozwala na jego wykorzystanie zarówno na poziomie lokalnym jak i międzynarodowym. Umożliwia porównanie praktyki pielęgniarskiej w czasie, między ośrodkami klinicznymi, populacjami pacjentów oraz obszarami geograficznymi. Identyfikuje również wkład pielęgniarki 
w pracę interdyscyplinarnego zespołu terapeutycznego. ICNP® jest elementem podkreślającym udział pielęgniarek w standaryzację świadczeń w ochronie zdrowia. Stanowi narzędzie oceny jakości opieki pielęgniarskiej [9].

Mononukleoza zakaźna jest (MZ) jest chorobą wywołaną przez wirus Ebsteina-Barr (EBV). Należy on do rodzinyHerpesviridae, do której zalicza się również wirusy opryszczki pospolitej (Herpessimplex), półpaśca i ospy wietrznej (Varicella zoster) [1]. EBV występuje u 90\% ludzi, u których wywołał zakażenie utajone. Obecny jest $\mathrm{w}$ organizmie do końca życia [2]. Zakazić możemy się poprzez kontakt ze śliną, krwią, preparatami krwiopochodnymi i przez przeszczepione narządy [4]. Zachorowania nie mają związku z płcią, porą roku czy pochodzeniem etnicznym $[5,8]$.

Najczęstszą objawową postacią zakażenia EBV jest mononukleoza zakaźna. Charakterystyczna w jej przebiegu jest triada objawów: zapalenie gardła, gorączka, limfadenopatia szyjna oraz hepatosplenomegalia i niekiedy wysypka plamistogrudkowa [5]. Bardzo często mononukleoza jest leczona nieprawidłowo antybiotykami z powodu błędnego rozpoznania jest bowiem mylona $\mathrm{z}$ nadkażeniami wywołanymi przez paciorkowce. Przebiega zazwyczaj łagodnie i trwa kilka tygodni. Powikłania występują rzadko, ale są bardzo ciężkie. Zaliczyć do ich możemy: powikłania hematologiczne, neurologiczne, zapalenie: trzustki, mięśnia sercowego, nerek, jąder, powikłania układu oddechowego czy pęknięcie śledziony [8].

Badaniami diagnostycznymi wykonywanymi w celu rozpoznania mononukleozy zakaźnej są: oznaczenie poziomu CRP, morfologia $\mathrm{z}$ rozmazem mikroskopowym, oznaczenie przeciwciał heterofilnych oraz aktywności transaminaz wątrobowych. W przypadku niejednoznacznych objawów i wyników badań oznacza się swoiste przeciwciała przeciwko antygenom wczesnemu, kapsydowemu i jądrowemu [5]. 
MZ jest chorobą samoograniczającą się, rzadko wymagającą leczenia farmakologicznego. Stosowane leki mają łagodzić objawy i są to: leki przeciwgorączkowe oraz steroidy stosowane z powodu obturacji górnych dróg oddechowych [3]. Terapia antywirusowa nie jest zalecana [7].

Celem pracy było zaprezentowanie planu opieki pielęgniarskiej nad dzieckiem z mononukleozą zakaźną z zastosowaniem klasycznej terminologii oraz pojęć z ICNP® (wersja 2017r).

\section{Prezentacja przypadku}

W pracy wykorzystano metodę studium przypadku w celu zebrania i uporządkowania danych do opracowania zindywidualizowanego planu opieki pielęgniarskiej. Terminy opisujące praktykę pielęgniarską zaczerpnięto ze słownika ICNP®. Zastosowano także metodę analizy literatury poświęconej zagadnieniom opieki nad dziećmi z mononukleozą zakaźną.

Dziecko 7-letnie przyjęte do oddziału dziecięcego z podejrzeniem mononukleozy zakaźnej. Z wywiadu, przeprowadzonego $\mathrm{z}$ matką dziecka $\mathrm{w}$ dniu przyjęcia wynika, że gorączkowało ono od $7 \mathrm{dni}$. Temperatura ciała wzrastała nawet do $39,0^{\circ} \mathrm{C}$. Dziecko zgłaszało również ból gardła oraz złe samopoczucie, osłabienie, brak apetytu. Dołączyły się bóle głowy, utrudniony oddech z powodu powiększonych migdałków i węzłów chłonnych. Dziewczynka skarżyła się również na ból brzucha.

Powodem hospitalizacji dziecka był brak poprawy jego stanu pomimo antybiotykoterapii zleconej przez lekarza podstawowej opieki zdrowotnej oraz konieczność przeprowadzenia pogłębionej diagnostyki w kierunku mononukleozy zakaźnej.

W dniu przyjęcia masa ciała wynosiła $21 \mathrm{~kg}$, wzrost $-123 \mathrm{~cm}$, temperatura ciała $-38,8^{\circ} \mathrm{C}$. Dziecko w stanie zdrowia średnim, cierpiące, $\mathrm{z}$ utrudnionym oddechem. W badaniu fizykalnym 
stwierdzono powiększone węzły chłonne szyjne, bolesne i powiększone migdałki pokryte charakterystycznym wysiękiem przypominającym anginę paciorkowcową. Język był obłożony szarym nalotem, śluzówki podsychające. Wątroba wystawała $2 \mathrm{~cm}$ spod łuku żebrowego.

Dziewczynka była wystraszona hospitalizacją oraz wykonywanymi badaniami diagnostycznymi. Uspokajała ją obecność matki, która współpracowała $\mathrm{z}$ personelem medycznym przy wykonywanych zabiegach. Matka nie posiadała wiedzy na temat choroby i zasad pielęgnacji dziecka.

Po przyjęciu pobrano krew do badań laboratoryjnych a ich wyniki potwierdziły rozpoznanie wstępne. Wdrożono zatem leczenie. W 14. dobie hospitalizacji dziecko w stanie zdrowia dobrym zostało wypisane do domu $\mathrm{z}$ dalszymi zaleceniami: kontynuacja leczenia doustnego, kontrola w poradni hepatologicznej, unikanie nadmiernego wysiłku fizycznego, zwolnienie z lekcji WF przez 2 miesiące, dieta lekkostrawna.

\section{Proces pielęgnowania dziecka $w$ przebiegu mononukleozy zakaźnej}

Diagnoza 1: Trudności w oddychaniu spowodowane powiększonymi migdałkami, węzłami chłonnymi. ICNP ®: Zaburzona drożność dróg oddechowych [10001051] Interwencje:

- Ocenianie statusu fizjologicznego [10030694]

- Zarządzanie bezpieczeństwem środowiska [10024706] + powietrze [10002061]

- Pozycjonowanie pacjenta [10014761]

- Nauczanie o terapii inhalacyjnej [10044835]

- Administrowanie lekiem [10025444]

- Monitorowanie odpowiedzi na leczenie [10032109] 
WYNIK ICNP @: Efektywne udrożnienie dróg oddechowych [10027964]

Diagnoza 2: Gorączka przebiegająca $\mathrm{z}$ osłabieniem, wzmożoną potliwością i okresowo występującymi dreszczami.

ICNP®: Gorączka [10041539]

Interwencje:

- Zmierzenie temperatury ciała [10032006]

- Monitorowanie temperatury ciała [10012165]

- Ewaluacja odpowiedzi na termoregulację[10007195]

- Administrowanie lekiem przeciwgorączkowym[10037248]

- Monitorowanie odpowiedzi na leczenie [10032109]

- Asystowanie w higienie 10030821 (+ pościel [10003175]/ ubranie [10002589]

- Kąpanie pacjenta [10045986]

WYNIK ICNP ®: Efektywna termoregulacja [10033848]

Diagnoza 3: Ryzyko odwodnienia spowodowane gorączką i niedostateczną podażą płynów ICNP®: Ryzyko odwodnienia [10041895]

Interwencje:

- Ocenianie skóry [10041126]

- Ocenianie statusu jamy ustnej [10044202]

- Monitorowanie przyjmowania płynów [10035303]

- Monitorowanie wydalanych płynów [10035319]

- Monitorowanie równowagi płynów [10040852]

- Zmierzenie tętna [10036826]

- Monitorowanie ciśnienia krwi [10032052]

- Monitorowanie temperatury ciała [10012165]

- Nauczanie o przyjmowaniu płynów [10032939]+nauczanie opiekuna [10033086]

WYNIK ICNP ®: Nawodnienie adekwatne [10042065] 
Diagnoza 4: Zmniejszony apetyt ze względu na trudności w połykaniu w związku z powiększonymi migdałkami.

WYNIK ICNP®: Brak apetytu [10033399]

Interwencje:

- Karmienie[10007786]+technika karmienia[10007819]

- Ważenie pacjenta[100033323]

- Nauczanie o potrzebach dietetycznych [10046533]

- Asystowanie w jedzeniu i piciu [10037269]

- Monitorowanie odżywiania [10036032]

- Monitorowanie spożycia pokarmów [10036614]

- Ocenianie postawy wobec statusu odżywienia[10002694]

- Ocenianie zachowań związanych z jedzeniem lub piciem [10002747]

- Ocenianie ryzyka zaburzonego statusu odżywienia 10040921]

WYNIK ICNP ®: Dobry apetyt [10040333]

Diagnoza 5: Brak wiedzy opiekunów na temat mononukleozy zakaźnej oraz możliwych jej powikłań

WYNIK ICNP®: Brak wiedzy o chorobie [10021994] + opiekun [10003958]

Interwencje:

- Ocenianie wiedzy opiekuna [10033876]

- Ocenianie gotowości do uczenia się [10002781]+opiekun [10003958]

- Ocenianie postawy wobec statusu zdrowotnego[10040636]+ opiekun [10003958]

- Ocenianie postawy wobec reżimu terapii [10024205]+ opiekun [10003958]

- Ocenianie postawy wobec choroby [10024192]+ opiekun [10003958] 
- Promowanie przestrzegania zaleceń dotyczących leków [10038051]

- Wspieranie opiekuna [10024570]

WYNIK ICNP ®: Wiedza adekwatna [10027112] + opiekun [10003958]

\section{Wnioski}

ICNP® to system zmierzający do tworzenia ujednoliconej specjalistycznej terminologii, która ułatwi komunikację pielęgniarek w skali europejskiej i międzynarodowej. ICNP® jest też klasyfikacją terminów zawierających dane dotyczące praktyki pielęgniarskiej, które gromadzone są $\mathrm{w}$ ramach procesu pielęgnowania. Zaprezentowany $\mathrm{w}$ niniejszej pracy plan opieki stanowi jedynie propozycję korzystania $\mathrm{z}$ klasyfikacji $\quad$ ICNP® ${ }^{\circledR}$ dla potrzeb dokumentowania praktyki pielęgniarskiej.

\section{Bibliografia/Bibliography:}

1. Bocian J., Januszkiewicz-Lewandowska D. : Zakażenia EBV - cykl życiowy, metody diagnostyki, chorobotwórczość. Postępy Higieny i Medycyny Doświadczalnej. 2011; 65: 286-289

2. C. de Martel, S. Francesci : Infection and cancer - established associations and new hypotheses. Critical Reviews in Oncology/Hematology. 2009: 70: 183-194

3. Gajewski P., Szczeklik A.: Interna Szczeklika. Medycyna Praktyczna. Kraków 2017: 2383-2385

4. Kalicki B., Maślany A., Milart J., Jung A.: Przebieg i diagnostyka zakażenia EBV u dzieci - obserwacje kliniczne. Pediatria i Medycyna Rodzinna. 2011,7(3): 247-252 
5. Leś K., Przybylski M., Łazińska B.: Diagnostyka laboratoryjna mononukleozy zakaźnej u chorych leczonych ambulatoryjnie. Postępy Nauk Medycznych 2015,4b: 42-47

6. Ołdak E.: Mononukleoza zakaźna. Pediatria po Dyplomie 2012, 16, 6:15-21

7. Strobel S. i inni: Choroby wieku dziecięcego. Wyd. Lek. PZWL, Warszawa 2010:74

8. Wrembel J.M., Jarmoliński T.: Mononukleoza zakaźna u dzieci doświadczenia własne. Postępy Nauk Medycznych 2016, XXIX(6): 391-396

9. Kilańska D. (red. Nauk.): Międzynarodowa klasyfikacja praktyki pielęgniarskiej - ICNP® w praktyce pielęgniarskie. Wyd. Lek. PZWL, Warszawa 2014

10.http://www.nursing.com.pl/ArchiwumMagazynuPiP_Miedzynarodow a_Klasyfikacja_Praktyki_Pielegniarskiej_Historia_powstania_61.ht $\mathrm{ml}$ (dostęp z dnia 5.11.2018r).

11. http://www.old.icn.ch/what-we-do/ICNP-Browser/(dostęp z dnia 5.11.2018r). 